\title{
'A Long Battle Ahead': Malaysian and Singaporean Prime Ministers Employ War Metaphors for COVID-19
}

\author{
Kumaran Rajandran \\ rkumaran@usm.my \\ School of Humanities, \\ Universiti Sains Malaysia
}

\begin{abstract}
The short article reports a preliminary exploration about how the Prime Ministers of Malaysia and Singapore frame COVID-19 through metaphors. The framing can shape our understanding of the virus. The Prime Ministers gave public broadcasts on or to the media in March, April and May 2020. The analysis of the broadcasts is comprised of metaphor identification using the Metaphor Identification Procedure (MIP), and metaphor interpretation. COVID-19 in the Prime Ministers' broadcasts is conceptualized by a few metaphors. The Prime Ministers utilize similar metaphors about the virus because metaphors of direction, journey, liquid and war are noted. COVID-19 IS WAR is selected because war metaphors have been recognized for other diseases and they have been commonly deployed during this pandemic. War metaphors frame several aspects of the virus, which cover its description, impact on multiple areas, the actors involved and their reactions. The war scenario can evoke a sense of alarm regarding the threat and severity of COVID-19.
\end{abstract}

Keywords: COVID-19; discourse; politics; metaphor; Malaysia; Singapore

\section{INTRODUCTION}

The Prime Ministers of Malaysia and Singapore declared war in March 2020. They did not declare war against one another but war against COVID-19, a new respiratory disease. The virus causing the disease was first detected in Wuhan, China in November 2019 but it soon spread to various countries. The global impact was known in less than 3 months and the World Health Organization declared COVID-19 a pandemic on 11 March 2020. In Southeast Asia, Malaysia and Singapore are the hardest hit, recording almost 10 thousand and 55 thousand cases respectively (as of mid-August 2020) (Center for Strategic and International Studies, 2020). The virus has impacted multiple dimensions in the lives of Malaysians and Singaporeans. The obvious and primary dimension is health but other sociocultural dimensions (e.g. education, politics, religion, tourism) have not been spared because the two countries imposed strict restrictions on activities from March to May 2020. Malaysia and Singapore relaxed restrictions starting from June 2020 but may not completely remove them until massproduced vaccines are available.

Sociocultural dimensions are discursive because their practices are often articulated using discourse. For example, health involves testing for COVID-19 but it also involves explaining about testing. A study of discourse can complement studies in other disciplines that intend to understand the virus. One notable feature of discourse is metaphors (Rajandran, 2017). Metaphors are a cognitive heuristic because their use reifies mental representations of entities and events. Metaphors compare domains of experience, which provide a frame to guide understanding a topic (Charteris-Black, 2004). Their use frames a topic, and emphasizes or deemphasizes certain information. Metaphors trace how a source domain maps onto a target domain (Lakoff \& Johnson, 2003), where the source domain helps to understand the target domain. The source domain is based on physical or cultural experience and the target domain 
involves abstract or unfamiliar concepts (Gibbs, Lima \& Francozo, 2004). A linguistic metaphor is evidence of cognitive structure and it reveals an underlying conceptual metaphor (Lakoff \& Johnson, 2003).

Metaphors are common in everyday life (Lakoff \& Johnson, 2003) and are purposive (Charteris-Black, 2004). Their use is probable in relation to COVID-19 and should be manifested in multiple discourses. Political discourse is prone to metaphors (Charteris-Black, 2004; Lee, 2015; Rajandran, 2013) and provides an overview of national response to the virus. The short article reports a preliminary exploration about how the Prime Ministers of Malaysia and Singapore frame COVID-19 through metaphors. The framing can shape our understanding of the virus (Ribeiro et al., 2018). It encourages certain interpretations (Musolff, 2016), which can subsequently influence perception and behavior.

\section{METAPHORS ABOUT POLITICS AND DISEASES}

The short article is informed by metaphors about politics and diseases. Most research on metaphors about politics is centered on Europe or North America (Charteris-Black, 2004) although Malaysia and Singapore have received some interest. In contrast, research on metaphors about diseases is overwhelmingly European-centered. The short article helps to 'decenter' research by adopting a Southeast Asian focus.

Metaphors form part of the communicative practice in politics in various countries. Charteris-Black (2004) analyzes metaphors in American presidential speeches and British election manifestos. A few studies examine metaphors in Malaysian and Singaporean political discourse in terms of the merger, separation and possible re-merger of Malaysia and Singapore (Wee, 2001), economic program (Rajandran, 2013) and national education (Lee, 2015). The union between Malaysia and Singapore in the 1970s is framed as an unequal relationship, to enable shifting blame between the two countries (Wee, 2001). Metaphors remain productive in their political discourse in later years. Rajandran (2013) analyzes metaphors of direction, journey, plant and vehicle in speeches on an economic program by Malaysian Prime Minister Najib Razak. Lee (2015) explains metaphors of building, container, morality and remembering in speeches on national education by Singaporean Prime Minister Lee Hsien Loong. Lee (2015) and Rajandran (2013) indicate the ideological orientation of metaphors, where the Prime Ministers legitimize the economic program and national education. The metaphors strengthen government agency, maintain government-citizens binary, and normalize government management of the economy or education.

Metaphors can simplify explanations about diseases, and existing research has catalogued metaphors to refer to a few diseases. Sontag (1978) decries how language traces cancer and tuberculosis to emotional depravity, and Sontag (1989) notes how war metaphors stigmatize AIDS. Sontag $(1978,1989)$ advocates avoiding metaphors in favor of nonmetaphorical language. She has inspired research on the language of diseases.

Metaphors have acquired prominence in research because the complexity of diseases facilitates metaphor use. Ebola is underestimated in the British media because it is framed as a foreign disease (Joffe \& Haarhoff, 2002), but mad cow disease in the British media is blamed on the government and farmers because foreigners cannot be blamed (Washer, 2006). Diseases are often conceptualized in terms of violence. The British media report a war against foot and mouth disease (Nerlich, 2004) and render SARS a killer (Wallis \& Nerlich, 2005). Moreover, the British media explains avian flu using journey metaphors to imply its foreign genesis, and war metaphors to vindicate government measures (Koteyko, Brown \& Crawford, 2008). Beyond the United Kingdom, the Brazilian media describes Zika using war terms, which legitimizes certain representations of disease management but obscures gender and social 
inequalities (Ribeiro et al., 2018). The conceptualization of multiple diseases frames their description, the actors involved and their reactions.

COVID-19 was previously named the novel coronavirus but the metaphors to refer to it are not novel. The virus is described by several metaphors but war metaphors dominate the description, as noted by the media in France (Combes, 2020), Spain (Rico \& Herrero, 2020), United Kingdom (Tisdall, 2020) and United States (Pillar, 2020). The media reminds political leaders to avoid war metaphors, which simplify COVID-19, and categorize actors and reactions being for and against government actions and decisions. These metaphors could conceal the ideological orientation of their users, and their entailments may leave real world impact. War metaphors for COVID-19 are pervasive in Europe and North America, and they may also be seen in Southeast Asia.

Previous research has explicated metaphors about politics and diseases. The trend in their findings is the use of metaphors to frame a topic because it can justify how the government or citizens react. Research should diversify the selection of politicians, as it brings sociocultural diversity. Research should also be relevant and consider COVID-19, a new disease being actively researched in multiple disciplines. Hence, the short article extends existing research and studies how the Prime Ministers of Malaysia and Singapore conceptualize the virus through metaphors.

\section{METHODOLOGY}

The Prime Minister heads the government and becomes its metonymic spokesperson. He represents the government's opinions about COVID-19. The Prime Minister can impose his metaphors (Lakoff \& Johnson, 2003) and his powerful position ensures the spread of the metaphors in media, and the probable uptake of the metaphors by citizens. The Prime Ministers of Malaysia and Singapore give broadcasts on or to the media. The broadcasts form part of regular and typical communicative practice in the two countries. They appear to be an easy and fast medium for government-citizens communication.

The two Prime Ministers gave public broadcasts, consisting of interviews, speeches and statements on or to the media in March, April and May 2020. The months marked the start and peaking of COVID-19, which probably motivated the Prime Ministers to speak about the virus. Mr. Muhyiddin Yassin (Malaysian Prime Minister) had 13 broadcasts and Mr. Lee Hsien Loong (Singaporean Prime Minister) had 9 broadcasts during this period. The broadcasts are a mix of English and Malay in Malaysia, and English, Malay and Mandarin in Singapore. Malaysia and Singapore are considered because the two countries share similar ethnic, linguistic and religious diversity, besides their intertwining geography and history.

The analysis employed the Metaphor Identification Procedure (MIP) to ensure an explicit and systematic qualitative method of metaphor identification (Pragglejaz Group, 2007). Firstly, I performed multiple readings of the broadcasts to understand their content. Secondly, I separated the lexical units, using slashes to mark their boundaries (e.g. The / virus / is / a / tough / enemy). Thirdly, I considered the contextual meaning (situation evoked) for the lexical units and decided whether these units had a basic meaning. The basic meaning tended to be more concrete, more precise than vague, and about physical or cultural experience (Pragglejaz Group, 2007). Whenever a contextual meaning contrasted with a basic meaning, the lexical units were marked as metaphorical.

The analysis revealed several linguistic metaphors. They were gathered into themes and a conceptual metaphor in the form of ' $\mathrm{X}$ is $\mathrm{Y}$ ' was proposed for a theme (Lakoff \& Johnson, 2003). Following metaphor convention, italics indicate a linguistic metaphor and CAPITALS indicate a conceptual metaphor (Musolff, 2016). After employing the MIP, metaphor 
interpretation was conducted. The functions of the metaphors were explored (Charteris-Black, 2004) by consulting the literature and prior knowledge about politics and diseases.

\section{ANALYSIS \& DISCUSSION}

COVID-19 in the Prime Ministers' broadcasts is conceptualized by a few metaphors. Their use reinforces the trend of representing diseases through metaphors (Ribeiro et al., 2018). The Prime Ministers of Malaysia and Singapore utilize similar metaphors about the virus because metaphors of direction, journey, liquid and war are noted. Space precludes a detailed explanation and I select COVID-19 IS WAR because war metaphors are pervasive. Moreover, they have been recognized for other diseases (Koteyko, Brown \& Crawford, 2008; Nerlich, 2004; Ribeiro et al., 2018; Sontag, 1989) and they have been commonly deployed during this pandemic (Combes, 2020; Pillar, 2020; Rico \& Herrero, 2020; Tisdall, 2020). War metaphors frame several aspects of the virus, which cover its description, impact on multiple areas, the actors involved and their reactions.

COVID-19 is described as an 'enemy' in Malaysia and Singapore. It is termed 'musuh senyap' (silent enemy) by Mr. Muhyiddin (10/05) and 'common enemy' by Mr. Lee (14/04). These metaphors entail a danger because enemies are harmful. The characteristics of the virus are mostly not provided although they were emerging after continuous study. Yet, the Prime Ministers employ minimal scientific description and their metaphors maintain the imprecise nature of COVID-19.

The virus is not a typical enemy because it is intangible. The five human senses only fathom it via symptoms, which enhances the danger. Enemies are considered to be external but COVID-19 is internal. Treatment must simultaneously harm the virus and heal the human body. Hence, the war against COVID-19 is 'unprecedented' (Muhyiddin, 27/03). The virus brings devastation because it can 'attack' and 'ravage' Malaysia (Muhyiddin, 04/05, 10/05).

Devastation is an impact of this pandemic but it is not specified because it spans a range of areas. The impact was primarily health from January to March 2020 but it also extended to various economic sectors from April to May 2020. The extension ensued because while the health impact was expected, the economic impact was becoming measurable. The impact became apparent as Malaysia and Singapore instituted restrictions on activities in March 2020. The restrictions had ramifications as they slowed agriculture, manufacturing and services. They are named a ' $h i t$ ' (Lee, 12/03), which makes the Singaporean economy a casualty.

The government and citizens are the actors involved in the war against COVID-19. They are named using the pronouns 'we', 'our', 'us' or 'kita' (inclusive we/our/us). The locus of the pronouns is tailored to the listeners. For example, Mr. Muhyiddin mentions 'We are a nation at war with invisible forces' (27/03) and Mr. Lee mentions 'We have been fighting' (27/03). The pronoun 'we' refers to citizens because it is employed in a public speech on national television. Mr. Muhyiddin says on $24^{\text {th }}$ March 'we can destroy this common invisible enemy' and Mr. Lee says on $14^{\text {th }}$ April 'We face a common enemy'. Because Mr. Muhyiddin is speaking to representatives of the United Nations and Mr. Lee is speaking to representatives of ASEAN, the pronoun 'we' means global and Southeast Asian citizens respectively. The pronouns foster consensus and give government directives a veneer of global or regional adoption. Their use inspires shared reactions, making it virtuous to adhere to these directives. Citizens are presumed to be united and should act cohesively during this pandemic.

The actors are mostly not specified and the Prime Ministers can mobilize anyone in their jurisdiction. Yet, one group is specified early, the infamous frontliner, a noun with military origin (Online Etymology Dictionary, 2020). Mr. Muhyiddin and Mr. Lee often thank frontliners. The metaphor first meant jobs in health and later other services. People in such jobs seem noble and their contribution is celebrated. The metaphor entails sacrifice but obscures the 
shortage of equipment and drugs, which probably precipitated a sacrifice. People in selected jobs are mystified, as if only they and their day-to-day tasks can hinder the virus. The burden of stopping COVID-19 is placed on some people, separating them from ordinary citizens. Understandably, these citizens may become absolved of precautionary measures. Mr. Lee is aware of this consequence, and 'enlists' ordinary citizens 'to join them (frontliners) on the frontline' (03/04).

The actors are responsible for reactions against the virus. These reactions are part of war, a frame explicitly deployed multiple times by Mr. Muhyiddin (e.g. 'this war' [06/04]) and Mr. Lee (e.g. 'in the midst of a battle' [30/03]). The duration of the war is long, and Mr. Lee warns Singaporeans about 'a long battle ahead' (30/03). The war acquires a religious aspect when Mr. Muhyiddin speaks at the start of the Muslim fasting month. He says 'kita berjihad melawan COVID-19' (we are fighting a jihad against COVID-19) (23/04), which makes the war a religious responsibility. A war requires weapons, and similarly, Mr. Muhyiddin acknowledges 'the arsenals in this war' (24/04). He evaluates developments positively, such as 'menunjukkan petanda kejayaan' (showing signs of victory) (10/05). The ultimate aim in any war is victory and Mr. Muhyiddin predicts that 'we will win' (10/04).

These metaphors convey a scenario (Musolff, 2016), where the meanings entailed can frame arguments. A war scenario is often deployed to refer to diseases (Koteyko, Brown \& Crawford, 2008; Nerlich, 2004; Ribeiro et al., 2018; Sontag, 1989) and the Prime Ministers reinforce the trend. The protection of Malaysia and Singapore acquires a combative frame because the war scenario can evoke a sense of alarm regarding the threat and severity of the virus. The Prime Ministers need to cater to citizens with varied knowledge of COVID-19. Mr. Muhyiddin and Mr. Lee may frame the virus through war metaphors because most citizens should have direct or most probably indirect experience of war. Because the schema is readily available in their cognition, it can be adapted to conceptualize COVID-19. The war scenario may reduce the cognitive demand on citizens because it simplifies explanations.

The scenario displays intertextual metaphoric coherence (Kövecses, 2010) because subsequent texts continue using and developing it. The coherence is manifested by two techniques. First, Mr. Muhyiddin and Mr. Lee gave several broadcasts from March to May 2020. They repeat the war scenario several times. The repetition entrenches the framing and may encourage its adoption by citizens. Second, people speak/write about and share the broadcasts. Journalistic reports, daily conversations, blogs and social media posts, among other texts, can reproduce the war scenario. The extent of the reproduction by journalists and ordinary citizens perpetuates the framing. The intertextual metaphoric coherence is continuous and cumulative. It empowers the war scenario to circulate in space (to other texts) and time (beyond March 2020). The circulation establishes common conceptual patterns (Musolff, 2016), which represent the virus in terms of its description, impact, actors and reactions in Malaysian and Singaporean political discourse.

The war scenario could obscure an ideological orientation, unsurprising in relation to politics and diseases (e.g. Ribeiro et al., 2018; Wee, 2001). The Prime Ministers' choice of metaphors is ideological because the scenario normalizes government management of COVID19. Governments can centralize control in order to mitigate the virus. It grants governments monopoly of actions and decisions. The monopoly reduces or negates personal or social autonomy, which is replaced by government-led order. It maintains government-citizens binary because citizens must either comply with or depend on the government. Yet, war is mostly optional but resolving COVID-19 is not optional for a country's survival. Metaphors are distractions (Sontag, 1989) and the war scenario may legitimize draconian actions and decisions while democratic practice is suspended. The scenario may rationalize relaxing or ignoring rights for people and the environment. Their reality could be changed by the persistent war-mongering in discourse. 


\section{CONCLUSION}

The short article has explored how the Prime Ministers of Malaysia and Singapore frame COVID-19 through war metaphors. The virus is unknowable via direct perception but metaphors can structure its framing in an understandable manner (Rajandran, 2017; Vengadasamy, 2011). The short article is a preliminary exploration and is not intended to be comprehensive. But it strengthens studies on metaphors as part of the communicative practice in Malaysian and Singaporean political discourse, which forms a basis for future research. It can further explore war metaphors and other metaphors- those of direction, journey and liquid. Future research may enrich a close reading of metaphors by adopting corpus software. It would cover a larger quantity of data and capture repeated conceptual patterns. Moreover, research can examine metaphors in various mediums, countries and languages. The focus does not have to be politicians but can involve journalists and importantly, ordinary citizens. It may reveal multimodal metaphors, where language and image conceptualize COVID-19 (Semino, 2008).

Previous health crises have provided feedback about suitable conceptualizations of diseases (Wallis \& Nerlich, 2005) but such feedback should be implemented to bring about changes. War metaphors are a prominent way but not the only way to think about the virus. Alternative metaphors exist, inspired by the domains of journey, music and sport (Rajandran, 2020). Their principal framing involves everyone's equal and joint contribution to overcome COVID-19. These alternative metaphors emphasize our shared humanity and they should be nurtured because their scenarios inspire solidarity, care, and physical and mental resilience during this pandemic. We need to manage and ultimately cure this deadly virus. As we do so, we also need to reframe COVID-19.

\section{ACKNOWLEDGEMENT}

This work is funded by Universiti Sains Malaysia under Grant 304/PHUMANITI/6315234.

\section{REFERENCES}

Center for Strategic and International Studies. (2020). Southeast Asia COVID-19 Tracker. Retrieved 10 August, 2020, from https://www.csis.org/programs/southeast-asiaprogram/southeast-asia-covid-19-tracker-0

Charteris-Black, J. (2004). Corpus approaches to critical metaphor analysis. New York: Palgrave.

Combes, M. (2020). Non, nous ne sommes pas en guerre. Nous sommes en pandémie. Et c'est bien assez. Retrieved 25 May, 2020, from https://blogs.mediapart.fr/maximecombes/blog/200320/non-nous-ne-sommes-pas-en-guerre-nous-sommes-enpandemie-et-cest-bien-assez?utm_source=twitter\&utm_medium=social\&utm_ campaign $=$ Sharing \&xtor $=\mathrm{CS} 3-67$

Gibbs, R., Lima, P. \& Francozo, E. (2004). Metaphor is grounded in embodied experience. Journal of Pragmatics. 36(7), 1189-1210.

Joffe, H. \& Haarhoff, G. (2002). Representations of far-flung illnesses: The case of Ebola in Britain. Social Science and Medicine. 54(6), 955-969.

Koteyko, N., Brown, B. \& Crawford, P. (2008). The dead parrot and the dying swan: The role of metaphor scenarios in UK press coverage of avian flu in the UK in 2005-2006. Metaphor and Symbol. 23(4), 242-261.

Kövecses, Z. (2010). Metaphor. Oxford: Oxford University Press.

Lakoff, G. \& Johnson, M. (2003). Metaphors We Live By. Chicago: University of Chicago Press. 
Lee, M. (2015). Critical metaphor analysis of citizenship education discourse. Public Relations Inquiry. 4(1), 99-123.

Musolff, A. (2016). Political Metaphor Analysis. London: Bloomsbury.

Nerlich, B. (2004). War on foot and mouth diseases in the UK, 2001: Towards a cultural understanding of agriculture. Agriculture and Human Values. 21(1), 15-25.

Online Etymology Dictionary. Front-line. Retrieved 25 May, 2020, from https://www.etymonline.com/word/front-line\#etymonline_v_33397

Pillar, R. (2020). Trump is wrong: Don't call the coronavirus crisis a 'war'. Retrieved 25 May, 2020, from https://nationalinterest.org/blog/paul-pillar/trump-wrong-dont-callcoronavirus-crisis-war-140117

Pragglejaz Group. (2007). MIP: A method for identifying metaphorically used words in discourse. Metaphor and Symbol. 22(1), 1-39.

Rajandran, K. (2013). Metaphors for Malaysia's economic transformation programme. Kajian Malaysia. 31(2), 19-35.

Rajandran, K. (2017). From matter to spirit: Metaphors of enlightenment in Bhagavad-gītā. GEMA Online ${ }^{\circledR}$ Journal of Language Studies. 17(2), 163-176.

Rajandran, K. (2020). Are we at war? Retrieved 10 August, 2020, from https://simplyspeaking.usm.my/index.php/society-humanity/63-are-we-at-war

Ribeiro, B., Hartley, S., Nerlich, B. \& Jaspal, R. (2018). Media coverage of the Zika crisis in Brazil: The construction of a 'war' frame that masked social and gender inequalities. Social Science and Medicine. 200, 137-144.

Rico, S. \& Herrero, Y. (2020). ¿Estamos en guerra? Retrieved 25 May, 2020, from https://ctxt.es/es/20200302/Firmas/31465/catastrofe-coronavirus-guerra-cuidadosciudadanos-ejercito-alba-rico-yayo-herrero.htm

Semino, E. (2008). Metaphor in Discourse. Cambridge: Cambridge University Press.

Sontag, S. (1978). Illness and Metaphor. New York: Farrar Straus \& Giroux.

Sontag, S. (1989). AIDS and its metaphors. New York: Farrar Straus \& Giroux.

Tisdall, S. (2020). Lay off those war metaphors, world leaders. You could be the next casualty. $\begin{array}{llll}\text { Retrieved } & 25 & \text { May, } & \text { 2020, }\end{array}$ https://www.theguardian.com/commentisfree/2020/mar/21/donald-trump-borisjohnson-coronavirus

Vengadasamy, R. (2011). Metaphor as ideological constructs for identity in Malaysian short stories. 3L: The Southeast Asian Journal of English Language Studies. 17, 99-107.

Wallis, P. \& Nerlich, B. (2005). Disease metaphors in new epidemics: The UK media framing of the 2003 SARS epidemic. Social Science and Medicine. 60(11), 2629-2639.

Washer, P. (2006). Representations of mad cow disease. Social Science and Medicine. 62(2), 457-466.

Wee, L. (2001). Divorce before marriage in the Singapore-Malaysia relationship: The invariance principle at work. Discourse and Society. 12(4), 535-549.

\section{ABOUT THE AUTHOR}

Kumaran Rajandran is a Senior Lecturer in Linguistics at the School of Humanities, Universiti Sains Malaysia. His research involves the multimodal study of corporate, historical, political and religious discourses. He also explores the articulation of identity and ideology in contemporary societies. 